\title{
BABUR'S EXEMPLARY LIFE AND DEEDS IN THE VIEWPOINT OF UZBEK WRITERS
}

\author{
Khayrullayeva Zuhra Chorikulovna ${ }^{1}$, \\ Khayrullayeva Xurshida Chorikulovna ${ }^{2}$ \\ ${ }^{I}$ English language teacher at school № 29, Bukhara city, Uzbekistan \\ ${ }^{2}$ Teacher of biology at school № 12, Bukhara city, Uzbekistan
}

Article DOI: https://doi.org/10.36713/epra9032

DOI No: 10.36713/epra9032

\begin{abstract}
This article researches on the life of Zahiriddin Muhammad Babur and his contribution to the development of literature, science, art and so on. In this case, various opinions of Uzbek writers about Babur are also revealed.

KEYWORDS: Zahiriddin Muhammad Babur, scholar, warrior, writer, king, dynasty, Timurids, scientist, translator.
\end{abstract}

\section{INTRODUCTION}

Every nation has great kings, great scholars, great writers and poets who clearly define the historical, cultural and national image. Zahiruddin Muhammad Babur is one of such great members of mankind. In the history of humanity, it is very rare to find people with incomparable personal abilities, talents and qualities.

Babur was a great king, a classical poet, a theoretician, a literary critic, a jurist, a linguist, an art historian and an ethnographer. The "Baburnama" alone is a clear example of his interest in more than twenty fields.

\section{MAIN PART}

King Babur was, first and foremost, the king, the founder of the Baburids dynasty. The Baburids may be the longest-running dynasty in world history. As a king, he often experienced the bitter pains of royal defeats and the glorious joys of victory. Being a great man like his father, he considered the Fergana region as a small place and moved to Samarkand. There he was defeated by Shaybanikhan and came to Kabul, and then became the ruler of a country as vast as India.

The great king Babur continued the great creative traditions of the Timurids in India: the restoration of magnificent palaces, the digging of canals, the creation of gardens, the patronage of literature, the patronage of science, and the just administration of the people was genuinely appreciated by his older children. The great son of India, the great statesman Jawaharlal Nehru, in his books "Discovery of India" and "A Look at World History", expressed the following sincere thoughts about Zahiruddin Muhammad Babur: "Babur is a charming person. He is a true example of the ruler of the Renaissance. He was a brave and enterprising man. Babur was one of the most cultured and attractive people in the world. He was far from being restricted and fanatical, like sectarianism. Babur loved art and especially literature."

A visitor to Panipat, India, today can see the scenes of Zahiruddin Muhammad Babur's historic victorious battle with Sultan Ibrahim Lodhi in an open-air museum in the city, and may be convinced of the great respect of the great Indian people for Babur.

As a great historical figure, Babur's personality has attracted the attention of European and American orientalists. The English historian Edward Holden first finds it necessary to compare Babur with the famous Julius Caesar: "Babur is more worthy of love than Caesar. He is described as a man of high character. "

Zahiriddin Muhammad wrote a novel about his childhood and adolescence. The English translator of the "Baburnama", William Erskin, compares Babur to the kings of Asia: "There is no king in Asia equal to Babur in generosity and courage, talent, love of science, art, and success." 


\section{EPRA International Journal of Research and Development (IJRD)}

Babur is a classic word artist, poet and writer who stands alongside the famous genius Alisher Navai. No Uzbek king or poet can compete with Babur in the field of art. Some of the essential characteristics of poetry are: punctuation (the ability to express new ideas), the skillful use of attractive art in moderation, magic, and the interpretation of passionate feelings of color. In addition, his autobiographical feature, which he boldly incorporated into classical poetry, also highlights Babur's poetry. This is the next feature that inspires the poet's sense of patriotism. Expressing nostalgia for his hometown in a poem, the King of India involuntarily draws the reader's attention to his strangeness from Andijan: "Baburnama" provides the reader with important and interesting information on religion, ethnography, anthropology, astronomy, medicine, military science, mathematics, gardening, urban planning, and even the interpretation of dreams. The gist of this work is that the discerning reader, who pays attention to the events, says: "Babur has no field he is not interested in and does not know". In fact, these wonderful qualities are unique to his multifaceted work.

Zahiriddin Muhammad Babur had great respect for Hoja Ubaydullah Ahror and their children and grandchildren. Two of Khoja's grandchildren were in Babur's service. In particular, Hoja Kalon's affection for Babur is explained by his lifelong service. Babur translated Khoja Ubaydullah Ahror the Persian prose "Walidiya" into Uzbek in a poetic way.

The importance of records in the history of culture is great. Writing is an important means of transmitting spiritual heritage, culture and art to future generations. The Turks have used many scripts in their long history, including the Turkic-Runic script, the Arabic script, and the Uyghur script. Babur was literate in Arabic and wrote texts in two or three languages throughout his life. So he invented a new script, the Baburi script, in order to improve it, to make it easier, and to eliminate all the shortcomings of reading the word. His courage was due, firstly, to his zeal for spirituality and literacy, and secondly, to his desire to make reading and writing easier.

The influence of Persian language and literature in Khorasan and Movarounnahr, India and Afghanistan, Iran and Turkey in the XV-XVI centuries can be explained by the words of the secretary and translator of "Baburnama": the translation of the work into Persian from India to Turkey it was a belief that it had reached the peoples and intellectuals of a very vast region. Referring to the "Baburnama", the translator writes: "This book is my 'Baburiya'. Commenting on the first Persian translation of Abdurahim Khanikhan, the son of Rashid Akhtar Nadvi Bayramkhan, who translated the "Baburnama" into Persian, he wrote: " King, writer, poet, and military leader Babur's "Vaqoe" (Events), later known as "Baburnama", is a diary description of an important part of the conscious life and work of Zahiriddin Muhammad Babur.

"Baburnama" is, first of all, a mature work of art. Interpretations of the artistic image, the ability to portray events in the eyes of the reader in all their reality, artistic work on the word, the strength of style - one of the features of this style is generosity and concise expression, the other - originality and, most importantly, sensitivity is a priority. In the ocean of events in Fergana, Kabul and India, Zahiruddin Muhammad Babur's powerful personality is clearly visible. The following is a remarkable statement by the English orientalist Monstuart Elfinston about the "Baburnama" and its protagonist: "His style is simple and masculine, lively and figurative. He vividly portrays the images, customs, and aspirations of his contemporaries. In this sense, this work is the only example of a truly historical image in Asia. Babur describes the appearance, dress, temperament and customs of a military man, describing countries, their climate, nature, economy, arts and crafts. But the author's brilliant character makes the work the most attractive."

\section{CONCLUSION}

In a sense, the events of the play are closely connected with his fateful adventures. Therefore, the reader who reads the book from beginning to end can clearly imagine the young Babur, the young prince Babur, the beloved Babur, the lifelong warrior Babur, the king and thinker, the loving father Babur, with all his victories, defeats, virtues and shortcomings. From the day he took up the pen, the author decided to write only the truth of the interpretation of events and opinions and information about people's personalities. Babur described his writings as followings: "The events that took place are true. I wrote in this way because it is necessary to make sure that every word is true and that every action is told exactly as it happened." When Babur evaluates each person, he tries to point out all his important qualities and flaws in his character. He does not allow exceptions, and even if he is a father, he adheres to these two necessary criteria. Not just for his father, but for himself. In our opinion, Babur is perfect in several ways. Zahiriddin Muhammad Babur is, first of all, a brave man. This trait often tests people with complex and multifaceted traits, because courage is tested not only with friends, but also with enemies. Many of the events in "Baburnama" repeatedly demonstrate the celebration of this heroic character of Babur.

That is why Pave de Courteil, who translated the "Baburnama" into French, gave a fair assessment of Babur: was able to both punish and pardon; he was a talented military man and a man of action, a 


\section{EPRA International Journal of Research and Development (IJRD)}

Volume: 6 | Issue: 12 | December 2021

- Peer Reviewed Journal

commander who could lead the troops skillfully and earn their trust."

\section{REFERENCE}

1. З.М.Бобур. Бобурнома.- Тошкент: Юлдузча нашриёти, 1989.

2. П.Қодиров. Юлдузли тунлар.- Тошкент: Шарқ нашриёт-матбаа аксиядорлик махририяти, 2006-543 б.

3. Khayrullayeva K.R. Interpretation of Zahiriddin Muhamad Babur's image in Uzbek and world literature. EPRA International Journal of Research and Development. Volume 5, Issue 5, May, 2020.

4. Khayrullayeva K.R. Description of Zahiriddin Babur's achievements in various fields in the works of uzbek and world authors. International journal Scientific and Applied Science. Volume 89, Issue 9, September, 2020.

5. Khayrullayeva K.R., Hakimova M.A., Ne'matova Z.T. Exemplary life of Babur Mirza in the interpretation of Stephen Meredith. JournalNXA Multidisciplinary Peer-Reviewed Journal. Volume 7, Issue 6. June.-2021.

6. Kamolov I.N., Khayrullayeva K.R., Quvvatova D.K. Image of Babur in the interpretation of Harold Lamb. Journal of Contemporary Issues in Business and Government. Vo. 27, No. 4, 2021.

7. A.S.Beveridge. Babur-Nama (Memoirs of Babur) Translation. - New Delhi: Taj Offset Press, 1970.- 1040p.

8. H.Lamb. Babur The Tiger: First of the great Moguls. - New York: Boubleday and company inc, 1961-351p.

9. J.Nehru. The discovery of India.- Oxford, New York: Oxford University Press, 1985- P.237-257.

10. Fernand Grenard. Baber first of the Moghuls.Thornton Butterworth Limited, London, 1931- P. 272.

11. S.M.Edwardes. Babur: diarist and despot.-Great Britain: London: A.M.Philpot LTD, 1926-162p.

12. S.M.Jaffar. The Mughal Empire from Babar Babar to Aurangzeb.- Peshawar: Ripon printing press, 1936- P.9-32.

13. https://uz.wikipedia.org/wiki/Bobur 